\title{
Radioactivity concentrations in common brands of cement in Nigeria
}

\author{
I.P. FARAI ${ }^{1}$, J.E. EJEH ${ }^{1}$
}

(Manuscript received 10 June 2006, accepted 21 September 2006)

ABSTRACT Radioactivity concentrations of ${ }^{238} \mathrm{U},{ }^{232} \mathrm{Th}$ and ${ }^{40} \mathrm{~K}$ in common brands of Portland cement in Nigeria have been measured using a shielded $7.6 \mathrm{~cm} \times 7.6 \mathrm{~cm}$ NaI(TI) detector coupled to a Canberra series 10 plus multichannel analyzer. The cement samples show significant spread in their radioactivity concentrations, even among samples of the same brand. The weighted means of the activity concentrations of ${ }^{238} \mathrm{U},{ }^{232} \mathrm{Th}$ and ${ }^{40} \mathrm{~K}$ in the different brands were $52.4,4.1$ and $91.8 \mathrm{~Bq} / \mathrm{kg}$, respectively. The radium equivalent ranged between 29.1 and $128.1 \mathrm{~Bq} / \mathrm{kg}$ with a weighted mean value of $68.5 \mathrm{~Bq} / \mathrm{kg}$. The values are lower than corresponding values in cement samples in most other countries as contained in recent publications. They are also lower than the UNSCEAR recommended maximum of $370 \mathrm{~Bq} / \mathrm{kg}$. The safety criteria developed by ITB Poland for radioactivity in building materials, especially for radon build-up in homes were however, exceeded in some of the cement samples.

Keywords: cement / Nigeria / gamma spectroscopy / radioactivity concentration / radiation exposure

RÉSUMÉ Radioactivité des ciments de grande diffusion au Nigéria.

Les concentration radioactives en ${ }^{238} \mathrm{U},{ }^{232} \mathrm{Th}$ et ${ }^{40} \mathrm{~K}$ dans des ciments de Portland de grande diffusion au Nigéria ont été mesurées en utilisant un détecteur NaI(TI) de $7,6 \mathrm{~cm} \times 7,6 \mathrm{~cm}$ couplé à un analyseur multicanal Canberra série $10+$. Les échantillons de ciment montrent une dispersion significative de la radioactivité au sein même d'une même marque. Les moyennes pondérées des concentrations en activité de ${ }^{238} \mathrm{U},{ }^{232} \mathrm{Th}$ et de ${ }^{40} \mathrm{~K}$ dans les différentes marques étaient $52,4,4,1$ et $91,8 \mathrm{~Bq} / \mathrm{kg}$, respectivement. L'équivalent en radium varie entre 29,1 et $128,1 \mathrm{~Bq} / \mathrm{kg}$ avec une valeur moyenne pondérée de $68,5 \mathrm{~Bq} / \mathrm{kg}$. Ces valeurs sont inférieures à celles mesurées dans des échantillons de ciment de la plupart des autres pays qui sont rapportées dans les publications récentes. Elles sont également inférieures à la valeur maximum de $370 \mathrm{~Bq} / \mathrm{kg}$ recommandée par l'UNSCEAR. Les critères de sûreté développés par ITB Pologne pour la radioactivité des matériaux de construction, particulièrement pour le radon dans les maisons étaient cependant dépassés dans certains échantillons de ciment.

\section{Introduction}

Radioactivity in cement, a vital component of building materials, is of significant importance in the assessment of population exposures. This is more so because most

\footnotetext{
${ }^{1}$ Department of Physics, University of Ibadan, Ibadan, Nigeria.
} 
individuals spend up to $80 \%$ of their time indoor. Elevated indoor external dose rates may result from high activities of radionuclides in building materials (Zikovsky and Kennedy, 1992). A radium equivalent of $370 \mathrm{~Bq} / \mathrm{kg}$ in building materials will produce an exposure of about $1.5 \mathrm{mSv} / \mathrm{y}$ to the inhabitants (UNSCEAR, 1982). Internal exposure may also arise from inhalation of radon, a naturally occurring radioactive gas found in soils, rocks and water. Two isotopes of this gas, ${ }^{222} \mathrm{Rn}$ $\left(\mathrm{T}_{1 / 2}=3.8 \mathrm{~d}\right)$ and ${ }^{220} \mathrm{Rn},\left(\mathrm{T}_{1 / 2}=55.6 \mathrm{~s}\right)$ are gaseous members of ${ }^{238} \mathrm{U}$ and ${ }^{232} \mathrm{Th}$ decay series, respectively. Being a gas, radon escapes readily from the walls and floors into the atmosphere and accumulate in indoor area. Since ${ }^{238} \mathrm{U},{ }^{232} \mathrm{Th}$ and ${ }^{40} \mathrm{~K}$ are ubiquitous radionuclides in the earth, the source of most raw materials for cement production; these radionuclides may find their ways into cement.

As a developing nation, the use of cement plays an important role in the national economy of Nigeria. This is evident in the yearly consumption of cement which is about 10 million tones, corresponding to about $75 \mathrm{~kg} / \mathrm{capita}$. The consumption has been on the increase at annual rates of between 10 and 15\% (Esubiyi, 1995). Accurate knowledge of radioactivity concentration in cement is important for checking its radiological effects on man and on the environment. Data are however, still quite sparse on the radioactivity of the different brands of cement in Nigeria (Farai and Ademola, 2005). The objective of this work is to measure the radioactivity concentration of ${ }^{238} \mathrm{U},{ }^{232} \mathrm{Th}$ and ${ }^{40} \mathrm{~K}$ in the various brands of Portland cement found in the Nigerian market and assess the health implications of the use of such cement products for the construction of buildings.

\section{Materials and method}

\subsection{Sample collection and preparation}

Cement manufacturing started in Nigeria in the early 1950s, the domestic industry has never been able to produce more than $30 \%$ of the national consumption level. As at 1993, the remaining 70\% was imported (Esubiyi, 1995). There is presently no accurate statistics on the number and production capacities of the local cement manufacturing companies. This is so because since the downturn of the economy in the last one decade, many of business ventures merely import finished cement products in bulk from their countries of origin and bag them with different brand names.

For the present survey, samples of ten common brands of cement were collected from the open market. The sampling exercise covered mainly South Western (SW) geopolitical zone and the Federal Capital Territory (FCT) where most of the brand names were found. However, samples of some brands found to be predominant in the North Central (NC) and South Eastern (SE) geopolitical zones were also 
RADIOACTIVITY CONCENTRATIONS IN COMMON BRANDS OF CEMENT IN NIGERIA

Table I

Sampling data and ranges of radioactivity concentrations.

Informations sur les prélèvements et variations des concentrations en radioactivité.

\begin{tabular}{|c|c|c|c|c|c|}
\hline \multirow[b]{2}{*}{ Brand } & \multirow{2}{*}{$\begin{array}{c}\text { No of } \\
\text { samples }\end{array}$} & \multirow{2}{*}{$\begin{array}{c}\text { Sampled } \\
\text { geopolitical zones }\end{array}$} & \multicolumn{3}{|c|}{ Activity concentrations $(\mathrm{Bq} / \mathrm{kg})$} \\
\hline & & & ${ }^{40} \mathrm{~K}$ & ${ }^{238} \mathrm{U}$ & ${ }^{232} \mathrm{Th}$ \\
\hline Dangote & 4 & SW, FCT & $150.3-180.2$ & $65.3-85.3$ & $5.0-6.2$ \\
\hline Elephant & 6 & SW, FCT & BDL-23.4 & $80.7-95.9$ & $5.4-6.4$ \\
\hline Ashaka & 2 & FCT & $88.3-113.9$ & $62.0-68.0$ & $4.6-4.9$ \\
\hline Rock & 2 & $\mathrm{NC}$ & $72.0-98.8$ & $6.5-27.6$ & $5.1-6.2$ \\
\hline Burcham & 4 & FCT, SW & $88.7-132.9$ & BDL-15.6 & BDL-10.5 \\
\hline Continental & 4 & FCT, SW & $95.5-116.7$ & $39.4-150.4$ & BDL-6.4 \\
\hline Gateway & 4 & SW & $106.1-127.0$ & $76.2-82.0$ & $5.2-6.1$ \\
\hline Elepvont & 2 & $\mathrm{NC}$ & $118.5-159.3$ & $6.4-15.9$ & $4.8-5.4$ \\
\hline Super camel & 4 & NC, SE & $140.2-181.5$ & $21.4-35.0$ & $5.0-8.0$ \\
\hline Aalborg white & 2 & $\mathrm{NC}$ & $62.1-95.6$ & $29.2-55.3$ & $4.8-6.5$ \\
\hline
\end{tabular}

collected. In all, 34 samples, comprising of two from each sampling point, were investigated. The number of samples of each brand collected, shown in Table I, is fairly representative of the relative abundance of each brand in the market. The Elephant brand was found to be quite ubiquitous. Apart from Aalborg White which was labeled as being imported from Denmark, it could not be clarified if all samples of the same brand were from the same bulk source. The samples were pulverized and packed $200 \mathrm{~g}$ by mass in clean radon impermeable cylindrical plastic containers which are $8 \mathrm{~cm}$ in height and $7 \mathrm{~cm}$ in diameter such that they fit the NaI detector crystal with good geometry. The containers were then hermitically sealed for upwards of 2 months to ensure secular equilibrium between ${ }^{226} \mathrm{Ra}\left({ }^{238} \mathrm{U}\right.$ series $)$ and ${ }^{232} \mathrm{Th}$ and their respective gaseous gamma emitting progenies.

\subsection{Experimental methods}

All measurements were made in a low-level gamma counting spectroscopy comprising of a $7.6 \mathrm{~cm} \times 7.6 \mathrm{~cm} \mathrm{NaI}$ (Tl) detector (Model 8020 by Bicron), which is coupled to a Canberra Series 10 plus Multichannel Analyzer (MCA) (Model 1104) through a preamplifier base. The detector assembly has a resolution of about $8 \%$ at $0.662 \mathrm{MeV}$ of ${ }^{137} \mathrm{Cs}$ which is capable of distinguishing the gamma ray energies of interest in the mixed spectrum of a typical cement sample. A reference pulverized soil sample, prepared from Rocketdyne Laboratories, California, USA which is traceable to a mixed standard gamma source (No. 48722-356) by Analytics 


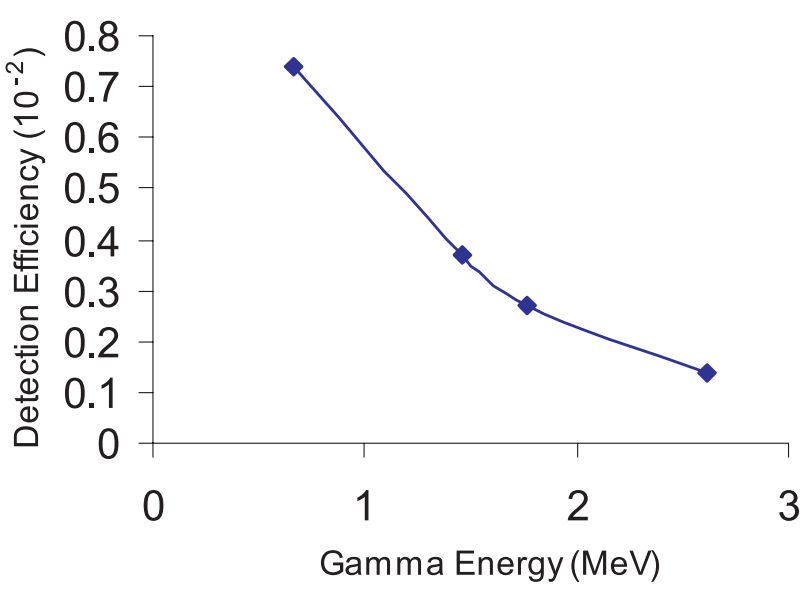

Figure 1 - Detection efficiency as a function of gamma energy.

Efficacité de detection en fonction de l'énergie gamma (en MeV).

Inc., Atlanta, Georgia was counted for $10 \mathrm{hrs}$ to determine the detection efficiency $E_{p}$ of the system, which at constant matrix and geometry, is defined as:

$$
E_{p}=\frac{C}{t A_{r} Y m}
$$

where $C$ is the net count above the background after counting a reference sample of known activity $A_{r}(\mathrm{~Bq} / \mathrm{kg})$ and mass $m(\mathrm{~kg})$ for a time $t(\mathrm{~s})$ and $Y$ is the gamma yield. The efficiency was determined for the energy range $0.66-2.62 \mathrm{MeV}$. The reference sample has a fairly similar matrix as the pulverized cement samples. The cement samples too were counted for $10 \mathrm{hrs}(36,000 \mathrm{~s})$ at same geometry.

The efficiency of the detection system as a function of gamma energy is shown in Figure 1. The detection limits of the detection system (IAEA, 1989; Oni, 2004) are given in Table II together with the gamma energies used for the measurement of the three primordial radionuclides. The radioactivity concentrations of the radionuclides in each cement sample were obtained by relating the detection efficiency obtained from calibration, to the net count under each photopeak at the end of each counting exercise.

\section{Results and discussion}

The ranges of radioactivity of each radionuclide in the ten brands are given in Table I. The arithmetic means are presented in Table III with the standard deviations given as the errors. The standard deviations give a measure of the spread in the 
Table II

Radionuclide detection limits of the system.

Limites de detection du système de mesure.

\begin{tabular}{cccc}
\hline Radionuclide & Energy $(\mathrm{MeV})$ & Detection efficiency $\left(\lambda_{\gamma}\right) \times 10^{-2}$ & Detection limit $(\mathrm{Bq} / \mathrm{kg})$ \\
\hline${ }^{137} \mathrm{Cs}$ & 0.662 & 1.120 & 1.05 \\
${ }^{40} \mathrm{~K}$ & 1.460 & 0.441 & 11.57 \\
${ }^{214} \mathrm{Bi}\left({ }^{226} \mathrm{Ra}\right)$ & 1.760 & 0.271 & 8.72 \\
${ }^{208} \mathrm{Tl}\left({ }^{228} \mathrm{Ra}\right)$ & 2.615 & 0.242 & 4.43 \\
\hline
\end{tabular}

Table III

Radioactivity concentrations and radiological health indices.

Concentration radioactive et critères de protection.

\begin{tabular}{|c|c|c|c|c|c|c|c|}
\hline S/No & Brand & $\begin{array}{c}{ }^{40} \mathrm{~K} \\
(\mathrm{~Bq} / \mathrm{kg})\end{array}$ & $\begin{array}{c}{ }^{238} \mathrm{U} \\
(\mathrm{Bq} / \mathrm{kg})\end{array}$ & $\begin{array}{c}{ }^{232} \mathrm{Th} \\
(\mathrm{Bq} / \mathrm{kg})\end{array}$ & $\begin{array}{c}\mathrm{Ra}_{\mathrm{eq}} \\
(\mathrm{Bq} / \mathrm{kg})\end{array}$ & $\mathrm{H}_{\mathrm{ex}}$ & $\overline{F_{1}}$ \\
\hline 1 & Dangote & $163.0 \pm 12.5$ & $77.3 \pm 8.5$ & $5.6 \pm 0.5$ & $97.9 \pm 10.1$ & 0.26 & 0.27 \\
\hline 2 & Elephant & $13.5 \pm 8.5$ & $75.9 \pm 8.1$ & $5.8 \pm 0.5$ & $85.2 \pm 9.4$ & 0.23 & 0.23 \\
\hline 3 & Ashaka & $101.1 \pm 18.1$ & $65 \pm 4.2$ & $4.7 \pm 0.2$ & $79.5 \pm 5.8$ & 0.21 & 0.22 \\
\hline 4 & Rock & $85.4 \pm 14.9$ & $17.0 \pm 14.9$ & $5.7 \pm 0.8$ & $31.7 \pm 17.1$ & 0.08 & 0.08 \\
\hline 5 & Burcham & $113.2 \pm 18.3$ & $10.7 \pm 4.0$ & $7.5 \pm 2.8$ & $30.1 \pm 9.3$ & 0.08 & 0.09 \\
\hline 6 & Continental & $103.8 \pm 10.7$ & $112.7 \pm 63.7$ & $5.2 \pm 1.7$ & $128.1 \pm 66.9$ & 0.35 & 0.36 \\
\hline 7 & Gateway & $117 \pm 9.7$ & $79.3 \pm 3.1$ & $5.7 \pm 0.4$ & $96.5 \pm 4.4$ & 0.25 & 0.26 \\
\hline 8 & Elepvont & $139.0 \pm 29.0$ & $11.15 \pm 6.7$ & $5.1 \pm 0.4$ & $29.1 \pm 9.3$ & 0.07 & 0.08 \\
\hline 9 & Super Camel & $160.6 \pm 20.7$ & $28.8 \pm 6.7$ & $6.7 \pm 1.4$ & $50.7 \pm 10.2$ & 0.13 & 0.15 \\
\hline \multirow[t]{2}{*}{10} & Aalborg White & $78.9 \pm 23.7$ & $42.3 \pm 18.5$ & $5.6 \pm 1.2$ & $56.4 \pm 21.9$ & 0.15 & 0.16 \\
\hline & Wt. Mean & 91.83 & 52.37 & 4.14 & 68.53 & & \\
\hline
\end{tabular}

values of radioactivity concentrations. The ranges of values are wide, resulting in large values of standard deviations. The weighted means, which give less importance to values with large errors and more importance to values with small errors, are also presented in Table III. These weighted means are compared with recently published data (El-Bahi, 2004) on other countries in Table IV. The weighted mean radioactivity concentrations in cement samples from Nigeria are less than the values for most of the countries. The values obtained for Th and $\mathrm{K}$ are much less than the respective global average concentrations of 41.0 and $230 \mathrm{~Bq} / \mathrm{kg}$ (UNSCEAR, 1982). The weighted mean for $U$ in the cement samples is interestingly, in very close proximity to the global average of $52.2 \mathrm{~Bq} / \mathrm{kg}$.

The weighted mean concentrations of the radionuclides in Table III are in the decreasing order $C_{T h}<C_{U}<C_{K}$. This order of activity concentrations is however 
Table IV

Comparison levels* of radionuclides for cement dry weight (in $\mathrm{Bq} / \mathrm{kg}$ ).

Comparaisons des niveaux de concentrations en radionucléides de différents ciments (en $\mathrm{Bq} / \mathrm{kg}$ ).

\begin{tabular}{cccc}
\hline Country region & ${ }^{238} \mathrm{U}$ & ${ }^{232} \mathrm{Th}$ & ${ }^{40} \mathrm{~K}$ \\
\hline California & - & 8.2 & 73 \\
USSR & 44.4 & 44.4 & 175 \\
Shenzhen & 55.2 & 26.4 & 127 \\
\hline Hong Kong & 19.2 & 18.9 & 93 \\
Egypt & 34.6 & 19.2 & 230 \\
Global Average & 52.2 & 41.0 & 91.8 \\
\hline Nigeria (present data) & 52.4 & 4.1 & \\
\hline
\end{tabular}

* Source: El-Bahi (2004).

not necessarily the order of their radiological health importance. In order to examine the total exposure caused by the three radionuclides, their radioactivity concentrations were combined in terms of radium equivalent, which is defined as:

$$
R a_{e q}=C_{R a}+1.43 C_{T h}+0.077 C_{K}
$$

where $C_{R a}, C_{T h}$ and $C_{K}$ are the respective radioactivity concentrations of $\mathrm{U}(\mathrm{Ra})$, $\mathrm{Th}$ and $\mathrm{K}$. The mean values of the radium equivalent and the associated errors due to the spread of the values are given in Table III. The overall weighted mean of the radium equivalent has been estimated with equation (2) from the values of the weighted mean of the radionuclides. This was estimated as $68.53 \mathrm{~Bq} / \mathrm{kg}$, which is much less than the maximum permissible limit of $370 \mathrm{~Bq} / \mathrm{kg}$ (UNSCEAR, 1982). The world average from Table IV is about $130 \mathrm{~Bq} / \mathrm{kg}$.

The radium equivalent, which gives the relative level of exposure rate caused by each brand of cement, is displayed in Figure 2. Continental brand gives the highest level of radiation exposure rate. Its ${ }^{238} \mathrm{U}$ concentration $(112.7 \pm 63.7 \mathrm{~Bq} / \mathrm{kg})$ is much higher than the world average but its concentrations of the other radionuclides are much less with the result that its radium equivalent is much less than the maximum permissible level. Dangote brand has the next highest value of radium equivalent and also the next highest value of $U$ concentration. Rock, Burcham and Elepvont brands have the least radium equivalents of about $30 \mathrm{~Bq} / \mathrm{kg}$ each. The lowest concentrations of $\mathrm{K}(13.5 \pm 8.5 \mathrm{~Bq} / \mathrm{kg}), \mathrm{U}(10.7 \pm 4.0 \mathrm{~Bq} / \mathrm{kg})$ and Th $(4.7 \pm 0.2 \mathrm{~Bq} / \mathrm{kg})$ were measured in the Elephant, Burham and Ashaka brands, respectively. 


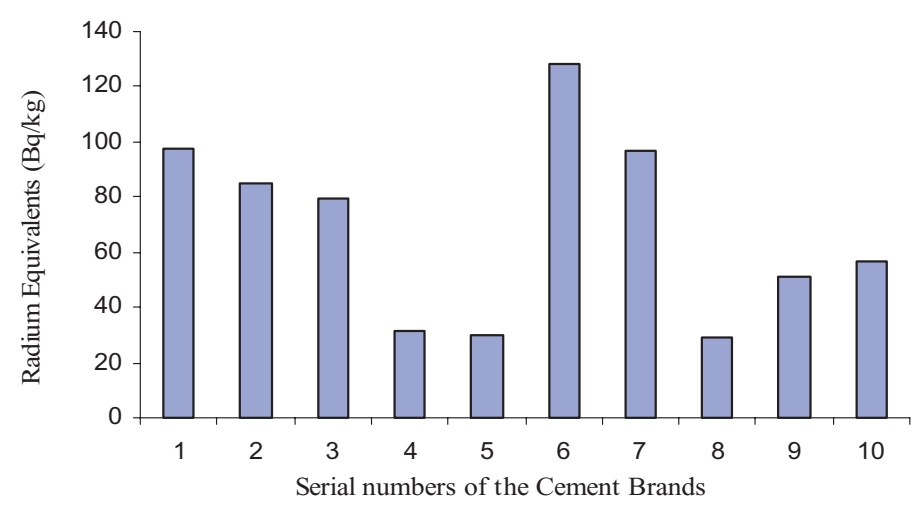

Figure 2 - Radium equivalents.

Équivalents radium.

The external hazard index $H_{\text {ext }}$ which estimates the potential radiological hazard posed by the different samples was calculated using the following equation

$$
H_{\text {ext }}=0.0027 C_{R a}+0.00386 C_{T h}+0.000208 C_{K}
$$

where $C_{R a}, C_{T h}$ and $C_{K}$ are the activity concentrations of $\mathrm{U}$, Th and $\mathrm{K}$ in $\mathrm{Bq} / \mathrm{kg}$, respectively. It is a dimensionless quantity and a safety criterion for materials used for building construction is that $H_{e x} \leq 1$ (UNSCEAR, 1993). The values of $H_{e x}$ obtained for the various brands of cement surveyed in this work are presented in Table III. The values of $H_{e x}$ ranged between 0.07 and 0.26 , showing that the safety criterion was met by all the brands.

Two criteria developed in Poland for the evaluation of radiological hazard posed by building materials to the environment are the qualification coefficients $F_{1}$ (no unit) and $F_{2}(\mathrm{~Bq} / \mathrm{kg})(\mathrm{El}-\mathrm{Bahi}, 2004)$. The two quantities are defined (ITB/CLOR, 1995) as:

$$
\begin{gathered}
F_{1}=0.0027 C_{R a}+0.0043 C_{T h}+0.00027 C_{K} \\
F_{2}=C_{R a}
\end{gathered}
$$

where $C_{R a}, C_{T h}$ and $C_{K}$ are the values of concentration of ${ }^{238} \mathrm{U},{ }^{232} \mathrm{Th}$ and ${ }^{40} \mathrm{~K}$ in $\mathrm{Bq} / \mathrm{kg}$, respectively. The quantity $F_{1}$ is dimensionless while $F_{2}$ has the dimension of $\mathrm{Bq} / \mathrm{kg}$. The safety criteria recommended by ITB, Poland are that $F_{1} \leq 0.29$ and $F_{2} \leq 50 \mathrm{~Bq} / \mathrm{kg}$. The values of $F_{1}$ obtained from the present survey ranged between 0.08 and 0.36 as shown in Table III. It can be observed from the same table that $F_{2}$ (U concentration) ranged between 11.15 and $112.7 \mathrm{~Bq} / \mathrm{kg}$. It can be observed that 
the values obtained are within acceptable range for $F_{1}$ and $F_{2}$ except in the Continental Brands for which the value of $F_{1}$ was 0.36 . The value of $F_{2}$ for the Continental brand of cement $(112.7 \mathrm{~Bq} / \mathrm{kg})$ is more than double the above Polish value of recommended maximum. The values of $F_{2}$ in the Dangote, Elephant and Ashaka brands as well as the weighted mean for all the ten brands, exceed the Polish recommended maximum value. The value of $F_{2}$ is a major determining factor in radon levels in homes constructed with these brands of cement. However, data are presently very sparse on radon levels in Nigerian homes and hence, there is for now no policy on radon levels in homes. The Polish criterion cannot be adopted or rejected without such data. Further work is urgent in this area.

\section{Conclusion}

Radioactivity levels in ten common brands of cement available in the open market in Nigeria have been measured in a low-level gamma counting spectroscopy. The values obtained are within UNSCEAR and ITB Poland safety criteria for radiation exposure due to radioactivity in building material, suggesting that the cement samples pose no major hazard of external radiation exposure. The criterion for safety from the point of view of radon build-up in dwellings was exceeded in more than half the number of cement sample surveyed. There is an urgent need for more studies on radon levels in homes.

\section{REFERENCES}

El-Bahi S.M. (2004) Assessment of Radioactivity and Radon Exhalation Rate in Egyptian Cement, Health Phys. 86, 517-522.

Esubiyi (1995) Technical Change in the Nigerian Cement Industry. Technology Policy and Practice in Africa, edited by Osita M. Ogbu, Banji O. Oyeyinka, and Hasa M. Mlawa, IDRC 1995, ISBN 0-88936-790-6, $380 \mathrm{pp}$.

Farai I.P., Ademola J.A. (2005) Radium Equivalent Activity Concentrations in Concrete Building Blocks in Eight Cities in Southwestern Nigeria, J. Environm. Rad. 79, 119-125.

IAEA (1989) Measurements of Radionuclides in Food and the Environment. International Atomic Energy Agency, Technical Reports Series 295, Vienna, Austria.

ITB/CLOR (1995) Institute of Building Technology and the Central Laboratory for Radiological Protection, Building Materials, Warszawa, Poland, ITB and CLOR, Instruction number 234; Pl-03-194, available at http://www.Clor-waw-pl/z-2/EngBuilding.htm.

Oni M.O. (2004) Natural Radioactivity Levels in River Sediments and Selected Aquatic Animal Species in the Coastal Areas of Nigeria, Ph.D. thesis, University of Ibadan.

UNSCEAR (1982) Ionizing Radiation: Sources and Biological, United Nations Scientific Committee on the Effects of Atomic Radiation, New York.

UNSCEAR (1993) Exposure from natural sources of radiation, United Nations Scientific Committee on the Effects of Atomic Radiation, New York.

Zikovsky L., Kennedy H. (1992) Radioactivity of Building Materials available in Canada, Health Phys. 63, $449-452$. 